This is an Accepted Manuscript of an article published by SAGE Publishing in Time \& Society on 29

April 2021, available online: https://journals.sagepub.com/doi/full/10.1177/0961463X211006082

\title{
The Signs of Frenetic Standstill: The Concept of Change in the Discourse of Lifelong Learning and The Tempo of the Czech National Qualifications Framework
}

\section{Tomáš Karger}

\begin{abstract}
The aim of this study is to interpret recent developments in the field of adult education in the Czech Republic through the theory of social acceleration. The study is designed as focused ethnography, drawing upon observation, interviewing, and document analysis. The material is read through the concepts of acceleration and frenetic standstill and contextualized in the discourses on industry 4.0 and recognition of prior learning. The study shows how the notion of constant technological change drives the Czech discourse of adult education, introducing a sense of urgency and pressing for faster developments in the further education of adults. However, the field of adult education exhibits a lack of consistency in its development, translating into absenting sense of progress. Within this context, the Czech National Qualifications Framework (NQF) has produced a steady output of qualification standards even though its internal processes have been prolonged. The tempo of the NQF and the absenting sense of progress can be read as signs of a frenetic standstill, accompanied by a high fluctuation of individuals on all levels of an organizational hierarchy. The study argues that acceleration is not driven by technological change in the observed context as the examined discourses expect. Instead, social acceleration seems to be perpetuating itself as a relatively independent force, eroding institutions that are seen as key in adapting to the incoming transition.
\end{abstract}

Keywords: social acceleration, frenetic standstill, adult education, industry 4.0, recognition of prior learning

\section{Introduction}

It has become a truism that the current rate of technological change requires constant learning on the part of individuals in order to adapt to its consequences. Change is not only continuous; it seems to be accelerating. So are the declarations of requirements placed on individuals spelled out as various forms of literacy, skills, or competence. Keeping pace with the ongoing development is the imperative of the day. It holds not only for individuals but also states and their bureaucracies, which have taken it upon themselves to facilitate this process. However, with considerable effort and resources expended, keeping pace is often all that is achieved. 
Frenetic standstill, a phenomenon accompanying social acceleration according to Hartmut Rosa (2013: 92), is at the center of this study examining the aspects of time in the functioning of the bureaucratic apparatus behind the Czech National Qualifications Framework (NQF). The framework is an extensive database of qualification standards (and mechanisms to create and award them) that has been established by law in 2006 and has been administered by the National Institute for Education (NIE). The NQF represents the only measure of the Czech State for supporting nonformal adult learning, a field in which organizations such as the United Nations Educational, Scientific and Cultural Organization (UNESCO), the Organisation for Economic Co-operation and Development (OECD), or the European Union (EU) have demonstrated a growing interest.

While examining the discourse on adult learning, it soon becomes apparent that beyond the economization and vocationalism already well described by others (Milana, 2017: 70), an indispensable part of the discourse is found in the notion of accelerating change. Learning represents a way to keep up with the pace set by the technological advancements in the economy so that the workforce does not meet the same fate as the obsolete technologies of yesterday. However, the paradox of the situation is that organizations that accept the discourse as their own and attempt to act on it are - at least viewed from the outside - inherently slow.

This study aims not to provide a descriptive account of the Czech system of adult education and its recent developments; it has already been done by others (Kopecký and Šerák, 2015). Instead, the aim is to interpret some of its developments by accounting for the relationship between discursive envisioning of the future on the one hand and a particular organizational tempo (as seen from the inside and the outside of the organization) on the other. To clarify further, the aim is not merely to provide a picture of an institutional setting that incidentally fails to meet its objectives. The theory of acceleration offers a compelling argument for seeing this as a result of broader structural forces at play.

The study draws from multiple sources of data gathered in the second half of 2019: 54 hours of observations at the National Institute for Education and at three events attended by its employees, five recorded interviews (ranging from 51 to 102 minutes) with stakeholders in the area of adult learning, field notes accounting for observations and interviews, and a close analysis of 41 documents (out of the total 298 documents gathered) including policy documents, organizational reports, or records of parliamentary debate. The data were gathered as a part of a broader research project focused on determinants of participation in non-formal adult education in the Czech Republic.

The following section elaborates the concepts of acceleration and frenetic standstill as tools for interpretation (Atkinson, 2017: 8) while contextualizing them in the discourses on industry 4.0 and recognition of prior learning. The rest of the text represents a thick description (Geertz, 1973) based on reading the data through the conceptual apparatus. First, it examines policy and other documents to show how the Czech discourse on adult education presupposes an incoming period of constant change that will stem from new developments in technology and the economy. Second, it draws upon other sources of data to account for the lack of continuous development in the field 
of adult education that would provide for a sense of progress in any direction. Instead, the NQF as the primary tool to support non-formal adult education - seems to have entered a state of frenetic standstill. Third, it accounts for how the NQF has been gradually repurposed during recent years to serve initial education. This shift could be interpreted as aligning institutions to match their tempo.

The study does not aim to present a full ethnographic account of the investigated setting. The strategy and extent of the study can instead be characterized as focused ethnography, that is, as examining a particular problem within a subculture of the researcher's own culture (Wall, 2015).

\section{From social acceleration to the recognition of prior learning}

Rosa (2013: 61) considers acceleration a defining characteristic of the modernization process. He suggests that the processes of differentiation, rationalization, individualization, and domestication of nature cease to unfold when they stop contributing to the acceleration. Indeed, institutions that facilitated acceleration in early modernity represent obstacles to speed at its later stages. The nation-state, once providing conditions for acceleration by homogenizing time, language, currency, or law, now represents a hindrance for global flows of exchange. Bureaucracy, once accelerating administrative processes through their rationalization, is now seen as a hurdle for social and economic development (Rosa, 2013: 206).

Modern institutions need to react to an increasing number of perturbations from an ever more complex environment. As Rosa (2013: 93) points out, this will lead either to their erosion or to a state of frenetic standstill, that is, "a situation brought about by the abandonment of a perspective and "path" of progress and characterized by the absence of any direction of development." Building upon this notion, Buddenberg and Hornberg (2017: 53-54) point to a phenomenon of "racing standstill" in the context of education systems. According to them, competition in benchmarking systems leads to an increasing effort by schools to maintain their position in various rankings. Seen from the outside, acceleration can result in some institutions entering a state of inertia. A standstill, be it frenetic or racing, is characterized by an expenditure of ever more resources to maintain the current state and by losing a perspective of any strong direction of development.

In order to provide sufficient depth to the notion of a standstill, the concept of acceleration must be further elaborated. Building upon the work of Niklas Luhmann, Rosa (2013: 184) sees temporalization of complexity as underpinning acceleration. By definition, complex systems cannot realize all possible interrelations among elements at once; they are bound to pursue options selectively. However, adding sequentiality compensates for limitations posed by the necessity to select. Unrealized options are not discarded. Instead, they are set aside for future pursuing (Luhmann, 1978: 97). The number of options grows more extensive, contributing to indeterminacy and exerting further pressure on later selections. As a result, the time that could be allocated to each option becomes shorter, reinforcing the tendency to accelerate. 
Rosa (2013: 64) also distinguishes three types of acceleration: technical, social, and the acceleration of the pace of life. Technical acceleration is derived from physical speed; that is, less time is needed to produce, transport, or compute. Social acceleration is exhibited through the increasing frequency of cycles such as the turnover of rulers/governments, jobs, or memberships. Finally, the acceleration of the pace of life is experienced as an increase in episodes of action per a given amount of time. A frenetic standstill then is a state that is conditioned by a heightened turnover of technologies, norms, workers, or decision-makers. This results in shortening the time horizon of predictability and an absence of expectations toward a more distant future, just as well as making the past outdated more quickly (Lübbe, 2009; Rosa, 2013: 113). The feeling of time pressure stemming from the acceleration of the pace of life is accompanied by an emphasis on the present, while a sense of continuity or progress is lost. In the teleology of acceleration, end-goals are substituted by a demand for ever higher speed (Sutherland, 2014: 56).

From this perspective, acceleration permeates every aspect of modern life. However, the various forms of acceleration do not just randomly feed into each other. Rosa (2013: 258-262) argues that there is a dominant pacesetter. Politics, which played this role in early modernity, has been succeeded by the economy. Technological advances employed toward economic ends set the pace, and thus determine which institutions are seen as either fast or slow. Moreover, the pace may not be set only by actual developments in the economy. There is also a vision of potential development that spills beyond its boundaries.

A current prime example of such vision is the notion of industry 4.0. Having originated in Germany in 2011, the term denotes an emergence of production that uses the latest developments in automation or artificial intelligence and controlling production elements through digital networks (Pfeiffer, 2017: 110). One of the central promises of industry 4.0 is a dramatic increase in efficiency of the manufacturing process, which could make large segments of human labor expendable. It is not the first time the employment of machines in production has threatened human labor. However, so far, the gains in efficiency have always been outpaced by the growth of the overall volume of production (Rosa, 2013: 69). As studies examining the future of jobs gain attention (Morgan, 2019: 385), the crucial question seems to be: is this time different?

Recent years have seen a mounting criticism of the revolutionarity associated with industry 4.0. Some authors identified consulting companies as the main drivers behind the notion (Pfeiffer, 2017: 114), while others questioned the methodology of studies estimating large segments of jobs to vanish (Morgan, 2019: 388). Still, others point out that the supposed fourth industrial revolution represents a development that is more continuous than revolutionary (Cetrulo and Nuvolari, 2019: 393). However, a sense of urgency has already spread beyond the discursive arena of its origins. Of particular interest here are the calls to anticipate the change by transforming educational curricula in initial education (Penprase, 2018) and an emphasis on continuous education, leading up to the concept of "learning society" (Ra et al., 2019: 34).

While some authors argue that lifelong learning is now a responsibility of each individual (Gleason, 2018: 7), creating suitable conditions for learning in every stage and walk of life has 
become a subject of much academic discussion and policy deliberation. The researchers in adult education and lifelong learning identify flexibility, openness, and accessibility as guiding principles (Boeren, 2016: 171; Desjardins and Ioannidou, 2020: 159). The corresponding metaphor of flexible learning pathways has been influential throughout a wide array of policy documents, indicating an approach to building systems that should provide learners with a sense of continuity and progress, the ability to choose among different pathways, points of transition through an articulation or credit transfer, and advisory services (Ramsaru, 2017: 75). Implementing measures associated with flexible learning pathways should help societies achieve better economic efficiency, social integration, and environmental sustainability (Villalba, 2020: 25; Duvekot, Coughlan and Aagard, 2017: 2; Lotz-Sisitka, Ramsaru and Bolton, 2017: 2).

One of the primary ways of supporting the flexibility of learning pathways is a recognition of prior learning (RPL). According to Desjardins (2020: 111; Desjardins and Ioannidou, 2020: 158), RPL is a "key feature" of advanced adult learning systems, and the flexibility it provides represents an essential factor for achieving high participation rates in adult education. RPL constitutes a framework for identifying existing competence, assessing it, and assigning value to it through certification, admission, or providing further learning opportunities. RPL is specifically designed to account for various forms of learning, including non-formal or informal learning outside educational institutions (Bolton, 2020: 3; Villalba, 2020: 25). As a result, it works toward the ideal of a learning society by turning every activity into an opportunity for learning, which can be formally recognized (Andersson et al., 2013: 407). Various national systems embodying the principles of RPL have been in existence for several decades now (Andersson et al., 2004: 58). There are cases of national systems that exhibit progress in implementing the principles mentioned above (Bolton, Matsau and Blom, 2020), and policy documents find numerous examples of good practice in partial aspects of implementation (Karttunen, 2020).

In the following sections, the study will turn to a certain type of obstacles toward the implementation of RPL systems and will focus on broader social conditions from which the obstacles arise. The researchers studying the implementation of RPL systems voice concerns over issues such as inclusivity (Cooper et al., 2017; Harris, 1999), vertical and horizontal mobility (Andersson and Fejes, 2010), or the colonization of lifeworld by formalized systems (Sandberg and Andersson, 2011). Consistently with the last issue, some studies on RPL mention overly bureaucratic procedures which objectify individual experiences and burden the process with further requirements (Hamer, 2010: 109; Sandberg and Kubiak, 2013: 351; Trowler, 1996: 26). Some reports on national RPL systems provide a more detailed illustration of the issue. For instance, after reviewing a series of reports on RPL in Australia, Smith and Clayton state the RPL process is "overly bureaucratic, time-consuming, costly, excessively detailed and difficult to understand" (Smith and Clayton, 2009: 13-14).

My argument is that this is not merely a matter of an incidental case of imperfect execution. The tendency toward excessive formalization of the recognition process has been observed across national contexts and directly clashes with the flexibility principle. In the national case examined 
in this study, the RPL system represents an attempt of governing bodies to face some of the pressing social issues (actual and expected). However, even after making the learning process completely indeterminate, the system still exhibits shortcomings similar to other bureaucracies. The formalization efforts that would aim at determining standard curricula moved their focus towards creating and maintaining assessment standards. One inevitably asks whether RPL systems can ever live up to the expectations given the nature of organizations that implement them.

\section{The Concept of Change in Czech Adult Education Policy}

Within the European context, one of the most influential policy documents on adult education and lifelong learning in recent decades is the European Commission's White Paper on Education and Training (Commission of European Communities, 1995). It starts with identifying an "upheaval" resulting from mutually reinforcing developments in three areas: information technologies, internationalization, and science and technology. The white paper predicts that dividing lines will be drawn between those who know and those who do not. The possession of appropriate knowledge will decide whether the upheaval will result in exclusion, or in seizing the opportunity. With such an outlook, the concept of "learning society" is offered as a solution. It is only by dismantling the barriers to learning and by making it more flexible (including recognition of skills individuals learned themselves) that European societies will be able to rise to the challenge. To add a sense of a profound historical change, the white paper concludes with a prominent historian comparing the current series of changes to the transition between the Middle Ages and the Renaissance.

This has become such a common trope for strategic documents on lifelong learning (e.g. Commission of the European Communities, 2000) that it even translated to key documents of a country that had not yet been a member state of the European Union at the time (MEYS, 2003) (for an overview of documents cited in this section, see Figure 1.). Six years after issuing the European white paper, the Czech Ministry of Education, Youth and Sports (Ministry of Education, or MEYS in the following) published its white paper on the matter. Appropriately, it begins with elaborating upon the major changes the society is undergoing:

\footnotetext{
Our society and the societies of Europe and the world undergo particularly wide and deep changes in the last fifty years. These changes are not waning, on the contrary, their breadth is widening and their pace is accelerating. They result from developments in science and technology and the corresponding growth of the economy, yet they interfere in all aspects of life and place ever more requirements on individuals, their training and faculties. The level of education, the quality and performance of the educational system and, above all, the ability of society to make use of the creative potential of its members have become determining factors of further developments in the society and the economy. (MEYS, 2001)
}

Such changes imply a need to react, and the document makes a strong call for the fast development of adult education in the country. It should saturate the constant need for innovation, heightening productivity, quality, effectivity, and competitiveness. However, such opportunities are also coupled with threats. Unless the Czech Republic adopts adult education with sufficient speed, it 
risks becoming a country with an obsolete workforce. ${ }^{1}$ A historical parallel is also drawn; this time, the adoption of lifelong learning is likened in its depth and radicality to the introduction of compulsory schooling in the beginnings of the industrial revolution.

It is important to note that the documents identify developments in science and technology (and their utilization in the economy) as key drivers of change. Even the increasing internationalization highlighted by the European White Paper (Commission of European Communities, 1995) could be seen as facilitated by developments in information and other technologies. This is consistent not only with the narrative of a revolutionary change that revolves around the notion of industry 4.0 but also with Rosa's theory in which the technologically enabled economic advances are setting the pace for the rest of the society. All of these discourses are, in a sense, technologically deterministic.

Seeing the source of change in technological developments, the expected transition is not treated as a process with a beginning and an end. In documents from around 2010 and later an emphasis is put on the continuous nature of the process instead (MEYS, 2010). It is argued that society is entering a new era of constant transition, one in which the only stabilizing factors are seen in managing their speed and direction:

It is true that the society and the economy are changing very fast and the pace is still accelerating. The education system will have to react, not with a single reform, but with constant reformation. This new approach to management of education will certainly not be accepted with enthusiasm by teachers, nor by the wider public. There have been many fundamental changes in the recent years and laments over never-ending changes are understandable. But changes cannot be prevented, it is necessary to learn to live with them. It is, however, necessary to prevent unsystematic change by aligning changes to a long-term goal, by explaining them properly and by shaping them to be incremental and have positive character (i.e. learning with examples of good practice and positive suggestions). (MEYS, 2009)

A further and last extension of such a concept of change is an inherent unknowability of the future. Transitions with beginnings and ends can be expected to bring inevitable consequences, even though the expectations may prove wrong. In the case of a continuous transition, the consequences are expected to expire soon or are not expected at all. This is particularly a problem for the initial education, where the time between planning changes and their effect on a cohort of students is very long compared to non-formal adult education. "Today, teachers prepare their pupils for a future that is unknown. Their role is now very different," a long-term NIE employee told me while finishing the trope of change at the beginning of our conversation about the NQF.

Even in the face of such uncertainty, the direction of future trends is still a lively topic. In 2015, the Office of the Government published a report on the expected consequences of digitalization. Methodologically, it was inspired by a study on the susceptibility of jobs to emerging digital technologies by Frey and Osborne (2017), now a cornerstone of the literature on industry

\footnotetext{
${ }^{1}$ The rationale of competitive workforce is also used in the introduction to the Strategy of Lifelong Learning in the Czech Republic (MEYS, 2007), though the document abstains from framing adult education into any sort of historical change.
} 
4.0. In line with the preceding strategic documents, the report makes a strong point of calling for further development of lifelong learning to avoid risks and reap benefits of the expected transition (Office of the Government of the Czech Republic, 2015). Further confirming that this is a topic belonging to the agenda of education, a 2017 report on industry 4.0 was released by the National Training Fund, a non-governmental organization led by a former minister of education. While it discusses some of the potentially unfavorable consequences of industry 4.0, such as the polarization of the labor market, weakening of the middle class, or the ratio between wages and capital earnings, it sees the transition as inevitable, with flexible education (putting emphasis specifically on the recognition of prior learning) being the only effective remedy. In its conclusion, it invokes the Danish concept of "flexicurity" to refer to the premise that the only way to stay secure in the upcoming upheaval is to be flexible (National Training Fund, 2017).

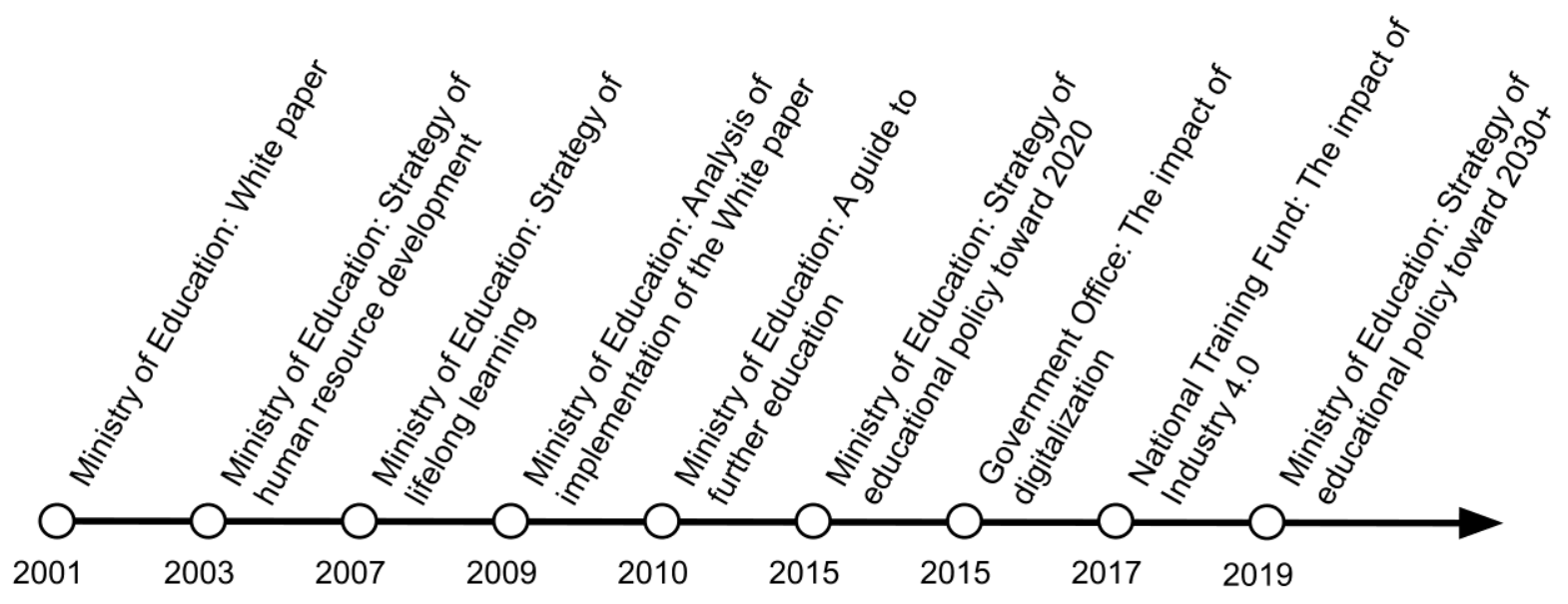

Figure 1. Timeline of selected documents

However, in contrast to the declarations of revolutionary change, the reaction of the state has been rather underwhelming. A comprehensive report on the implementation of measures suggested by the Czech White Paper (MEYS, 2001) states that even though the eight years between the white paper and the report have been saturated with economic growth and unprecedented support from the European structural funds, the measures suggested by the white paper were, by and large, not implemented. The document identifies two reasons for this. First, the turnover of individuals in decision-making positions has been too high. The report points out that during the eight-year period, six ministers have led the Ministry of Education under five different prime ministers (MEYS, 2009). And the pace does not slow down. In the decade following the report, another nine ministers have changed seats. This point was emphasized by an interviewee whose career as an educator of adults reaches the early 1990s: 
I'm afraid that the number of ministers of education and the number of ministers of labor is the answer to what the state does. Since 1989 we have the 19th minister of education and the 15 th minister of labor. The problem is that the state has no responsibility. No one speaks on behalf of the state. We pay the state from our taxes, and no one speaks on behalf of it because every now and then, a minister or a government is changed.

Here, the first contours of points that will be developed further can already be seen. While all the examined discourses expect a technology-driven change and call for measures to be taken in preparation, a proactive endeavor is marred by the (mostly unreflected) onset of social acceleration. The high turnover of decision-makers also brings the second reason identified by the report as a culprit - the absence of strategic management with a clear vision and political support. ${ }^{2}$ This means that the institution tasked with steering the rest of the society through an era of constant change is itself eroded by it. A lack of a long-term vision and a consistently followed strategy can only result in an absenting sense of progress, creating conditions suitable for the emergence of a frenetic standstill.

\section{The Signs of Frenetic Standstill in the National Qualifications Framework}

This section aims to make three points. First, it accounts for the perceived lack of consistent development in Czech adult education as one of the signs of the frenetic standstill. Second, it elaborates on the internal processes and outputs of the NQF to account for the second sign of the frenetic standstill (exerting more resources to keep pace). Third, it argues that both signs of the frenetic standstill are closely related to social acceleration, which manifests itself through an increased turnover of individuals.

Apart from general proclamations of its importance, non-formal adult education usually does not feature a prominent role in the strategic documents on the Czech education system. Some interviewees see this as a reflection of the Ministry's focus and point out that its name gives this away explicitly (even though the official translation is Ministry of Education, Youth and Sports, a literal translation would be Ministry of Schooling, Youth and Sports). Moreover, when asked whether adult education in the Czech Republic has a discernible direction of development, the interviewees working outside state agencies state that there is none. According to them, there are identifiable milestones such as entering the European Union in 2004 and the introduction of financial support from its funds. However, the milestones do not add up to provide a sense of progress. Each milestone had a limited influence and eventually became irrelevant. Even the European funds' support is now expected to gradually decrease, restructuring the educational market as radically as when it was introduced.

\footnotetext{
${ }^{2}$ Frequent changes in educational policy stemming from a high turnover of political representation have also been identified as a major issue by a recent report on challenges of the Czech educational system (Eduzměna Foundation, 2019).
} 
As an exception, the period between 2007 and 2013 was identified in the interviews as bringing a sense of progress for a limited time. During this period, a division of further education was established at the Ministry of Education. The NQF was beginning its vast growth, and an extensive project (codenamed Koncept) to bring a series of systemic changes favorable for further education was financed. The financial support for the NQF alone reached more than 638 million CZK (approx. 23 mil. EUR by today's rates) between 2005 and 2015. However, as interviewees described it, by 2013, the political support for adult education has vaned, the division of further education ended up understaffed and systemic measures remained mostly unimplemented.

The absenting sense of progress marks the first sign of the frenetic standstill. It is reinforced by the shortening of the time horizon (Rosa, 2013: 113), as new developments are not even expected to have a long-lasting effect. It further seems that there is a synergy between the absenting sense of progress and the shortening time horizon as described here and the notion of change as elaborated in the previous section. The image of the constant technological change and the urgent need to adapt translate into a stream of suggested measures. However, the measures are not expected to stay in effect for long and do not contribute to renewing the sense of progress.

In this context, the 15-year history of the NQF might provide a sense of continuity, but it too is not spared the effects of the frenetic standstill. The NQF was established in 2005 and has represented a central institutional measure the state has implemented in non-formal adult education. The framework consists of qualification and assessment standards and a network of individuals authorized to examine applicants and certify their competence. The process during which new standards are added into the framework involves the following main actors:

a) the National Institute for Education, which serves as an intermediary and organizer in the whole process,

b) sector councils, which are composed of representatives of employers, schools, relevant associations (such as the Confederation of Industry or the Chamber of Commerce), and the NIE,

c) workgroups within the sector councils that are tasked with designing particular standards,

d) validators, as employers not involved in the design process, who assess new standards before the authorization process is initiated,

e) authorization bodies, usually a ministry relevant for the sector, which provides an assessment of new standards and authorizes examinators to award certification,

f) the Ministry of Education, which reviews new standards and evaluates the work of NIE as its subordinate organization.

The list of actors also hints at the process through which the standards are designed and authorized. Length is the most interesting facet of this process. There is a whiteboard in one of the NIE's conference rooms, listing all of the 32 steps the process currently consists of. As it was repeatedly pointed out, the process was initially much shorter, taking only about eight months from 
proposing a new standard to having its complete version included in the NQF. Today, the process consists of approximately four months for pre-authorization, eight months of work on the standard, and 1-2 years of authorization. The authorization process, in particular, is seen as a "dead weight" for the framework. Moreover, the prolonged process applies to revisions of the existing qualification standards, which are just as important as maintaining the NQF as generating new standards. After all, the NQF is meant to provide a timely image of the demand for qualifications in the labor market.

Viewed from the outside, the NQF exhibits a relatively steady performance. The number of examinations seems to have stabilized at around twenty thousand per year. The number of new qualification standards holds at several dozen per year (with the exceptions of 2012 and 2015 - see Table 1.). Considering the increasing length of the process for the new standards and the need to update a growing amount of accumulated standards, there needs to be additional effort exerted to maintain the pace of output.

After the lacking sense of progress elaborated above, the prolongation of internal processes combined with the steady output marks another sign of frenetic standstill. It can be seen as a direct analogy to the phenomenon described by Buddenberg and Hornberg (2017: 53-54) as a "racing standstill." It is also worth noting that the two signs of the frenetic standstill are interrelated. All other things being equal, additional effort should translate into heightened output. That this proportionality is marred by the institutional environment brings the actual absenting sense of progress and calls into question whether progress can potentially be achieved.

\begin{tabular}{|c|c|c|c|c|c|c|c|c|}
\hline & $\mathbf{2 0 1 0}$ & $\mathbf{2 0 1 1}$ & $\mathbf{2 0 1 2}$ & $\mathbf{2 0 1 3}$ & $\mathbf{2 0 1 4}$ & $\mathbf{2 0 1 5}$ & $\mathbf{2 0 1 7}$ & $\mathbf{2 0 2 0}$ \\
\hline $\begin{array}{c}\text { Qualification } \\
\text { standards }\end{array}$ & 235 & 278 & 366 & 606 & 679 & 921 & 1194 & 1364 \\
\hline Examinations & 5 & 25 & 67 & 89 & 111 & 134 & 170 & 231 \\
& 402 & 086 & 107 & 544 & 110 & 195 & 568 & 462 \\
\hline
\end{tabular}

Table 1. Number of examinations and qualification standards in the NQF Note: The table was assembled from various NIE reports

To further develop the argument, the tempo of the NQF can be associated with various forms of fluctuation within the involved organizations. I began to notice this on my visit to a sector council meeting, where three changes in membership resulting from rank or employment shifts were announced as the first order of business. The council ended up not having a quorum that day, discussing the need to renew its membership. This kind of fluctuation represents an even bigger problem with regard to the authorization process. According to some NIE employees, the authorization process already suffers from the fact that state officials assess standards with little or no expertise in adult education or the field of the given qualification standard, resulting in higher than necessary demands on reporting and providing evidence. To make matters worse, the 
fluctuation of employees in the authorization bodies often blocks the whole process as the rationale and the procedures need to be explained repeatedly.

However, this is not only an individual matter. My time spent at the NIE coincided with the dissolution of the Further Education Fund (FEF), an organization run by the Ministry of Labor and Social Affairs specializing in administering projects from the European funds. At NIE, I met several people who were former FEF employees. Such transformations are not rare; NIE itself was established after a merger of three organizations in 2011 and was merged with another organization in January 2020, forming the National Pedagogical Institute. Naturally, each transformation means changes on various posts, translating into leaves, comings, or transfers. In contrast, the Association of Institutions of Adult Education (AIAE) - a non-governmental organization of educators - was founded in 1991 and continues its activities to this day. This continuity was compared to the fluctuations in state institutions by a member of the association:

I think that the AIAE has a great potential to lead in this direction. One reason is that we have great experience... long-standing... with negotiations of various kinds. And it also has historical memory, which, I think, many institutions, state institutions, in particular, do not have.

In this regard, historical memory represents the ability to maintain individuals with accumulated experience and knowledge crucial for an organization's performance. At NIE, this ability was threatened by the merger as employees fluent in the workings of the NQF were, at one point, about to leave the organization. An outsider well acquainted with the situation at NIE commented on the merger:

It [the NQF] is caught in a kind of turbulence, where there is growing insecurity. The question is, after the merger, if key people leave... and I regard [name] a key person from the perspective of historical memory. He was there since the beginning; this is invaluable. It is such a shame. And I have to say there were more cases like that.

In this interviewee's opinion, with such decisions, the state itself is threatening efforts that it supported for years with considerable amounts of resources. Instead of absorbing insecurity from the environment, it generates it by disrupting the continuity of its structures. However, as has been pointed out earlier, the state itself lacks continuity in strategy and decision-making roles. What seems to be happening here is perpetuating the turnover to all levels in the administrative hierarchy.

It is important to note that the increased turnover cannot be directly explained by any developments or implementations of new technologies. To be sure, the NQF did attempt to implement two digital information systems in recent years - one to manage the examination and certification process, the other to manage the work on qualification standards - but these ended up underused and resulted in multiplying communication channels rather than streamlining and speeding up the processes. ${ }^{3}$

\footnotetext{
${ }^{3}$ The unwillingness to use one of the systems was taken up by an amendment to the law, which brought the NQF into existence. The amendment, which reached the stage of public consultation in 2016, was intended to make its use mandatory. However, consistently with the argument developed so far, the amendment was dropped in favor of other priorities after a new minister of education came into office.
} 
Based on the evidence, it seems that instead of being driven by technological developments, social acceleration (or at least some of its aspects) is self-perpetuating. Social acceleration cannot be trivially deduced from digitalization or automation. Short-term political leadership, frequent reorganization, or the inability to maintain personal continuity all contribute in their own right to the state of constant flux in the administrative bodies. In these particular forms, social acceleration results in the shortening of periods during which one can expect continuity to last, be it the continuity of personnel or the continuity of purpose.

\section{Repurposing the National Qualifications Framework}

This section aims to account for the relationship between the NQF and institutions of formal education. While the relationship was present as a potentiality since the establishment of the NQF, it is only in the latest developments that this potential is realized. These developments can be read as an attempt to break away from the state of frenetic standstill by finding an alternate path for pursuing progress and by normalizing the slowdown of internal processes through a match with more similarly-paced institutions.

By June 2020, the NQF consisted of 1364 qualification standards in 27 fields, supplemented by 9627 examinators, and a total of 231472 successful examinations realized. However, an internal report from 2017 indicates that a disproportionate amount of examinations (around 70\%) is attributed to a single qualification standard, which is a mandatory requirement in the profession of security guards, and there is no other way to acquire it than through the mechanisms of the NQF. The second most common examination (around 5\%) corresponds to the qualification standard of sports massage. It is known to be a frequent option in retraining, which is now bound to use the $\mathrm{NQF}$ qualification standards. Examinations of other qualification standards are evenly distributed at around $1 \%$ or less. As a result, the NQF seems to be used mostly in cases where other parts of the state administration require it and not as a tool for voluntary personal growth.

The NQF also allows the acquirement of a formal education certificate (up to ISCED 3A) if an individual accumulates qualification certificates equivalent to it and passes an examination from the remaining subject matter. This option is seldom used as between 2010 and 2017, there were only lower hundreds of cases that took advantage of it, according to the internal report. Given that the minimum age requirement for undertaking an exam is 16 , the NQF could theoretically provide an alternative route to qualification for youth leaving the compulsory level of primary education at the age of 15 . Denying this route is the provision that examinations can be undertaken only as part of retraining under the age of 18 (which is the legal threshold for adulthood). As explicitly stated in the parliamentary debate over the provision, the state prefers schooling to other means of acquiring qualification (Parliament of the Czech Republic, 2011), a preference consistent with a gradual repurposing of the NQF to serve initial education. 
According to an NIE employee, the original idea behind the NQF was to grant the same formal weight to non-formal and informal learning as is assigned to formal education. In 2006, the NQF website presented its purpose with the following statement on the title page:

In the Czech Republic, there is currently work being done on the National Qualifications Framework $(\mathrm{NQF})$, which will succinctly describe qualifications so that they are comprehensible for schools, employers, and those interested in further education.

The NQF will help those who, for some reason, did not finish school and would want to complement their education. It will also help those who completed their education and worked outside of their field of study, hold the required knowledge and abilities but have no certificate. (National Institution of Technical and Vocational Education, 2006).

Schools were included in the original purpose as relevant recipients of qualification standards. The framework has been repeatedly introduced to me as constituting a common language for employers, HR specialists, adult learners, and educators (schools or adult education freelancers alike). As all of this complexity could not be realized at once, its temporalization (Rosa, 2013: 117) necessarily took place, allowing for selectivity while putting other options aside. The complexity was initially reduced by emphasizing learning outside of the formal educational system and recognizing its outcomes. The law from 2006 anchoring the NQF in the Czech legislation is titled The Act on Recognizing the Outcomes of Further Education. However, it seems that this emphasis has gradually changed by realizing connections that were initially present only as vague potentialities.

In the Strategy of Educational Policy of the Czech Republic Toward 2020 (MEYS 2015), the NQF is already seen as a possible source of curricular content for initial education, especially for secondary schools with a technical focus. Illustrating this is a shift in projects administered by NIE that use qualification standards from NQF (for an overview of the projects referenced in this section, see Figure 2.). Between 2005 and 2015, three iterations of a project codenamed UNIV aimed to turn secondary schools into lifelong learning centers by supporting them in becoming educators and examinators of qualification standards from the NQF. While the project sought to establish a network of organizations that would provide services associated with the NQF, it should also help mitigate the lowering numbers of students at schools due to demographic development. However, a central problem of the project was, as an NIE employee commented, that involvement in non-formal adult education, where numbers of participants change with every educational activity, proved to be too volatile for schools that are set to accept a class of students and educate it for several years.

In the same period, there were projects (such as PILOT S, or Kurikulum S) that focused on secondary schools' curriculum in initial education. The projects aimed to support implementing a state-wide curriculum reform that required schools to work out their own educational programs. It is important to note that these projects did not use qualification standards from the NQF. Instead, general educational programs were defined for each study field, which provided boundaries for school-specific programs. The use of $\mathrm{NQF}$ as a base for reforming initial education curricula came later. For example, the project MOV (2017 - 2020) uses NQF qualification standards to modularize 
secondary school educational content. I discussed the use of NQF standards for initial education at length with an NIE employee who argued that it would be more reliable to let schools pick from a set of pre-specified qualifications than to ask them to specify a general frame as the reform did. Therefore, it seems that currently, there is a shift in approaching how curricula in initial education are designed, which results in seeing the NQF as a stable set of standards to draw upon.

Moreover, recent efforts (organized as another EU-funded project codenamed MiZk) to extend the framework aim to introduce qualification standards certifying proficiency in craftsmanship. Focusing on exceptional competence in traditional crafts (which are formed over long periods) further moves away from the aim to serve as a flexible tool to account for new trends induced by the onset of developing technologies.

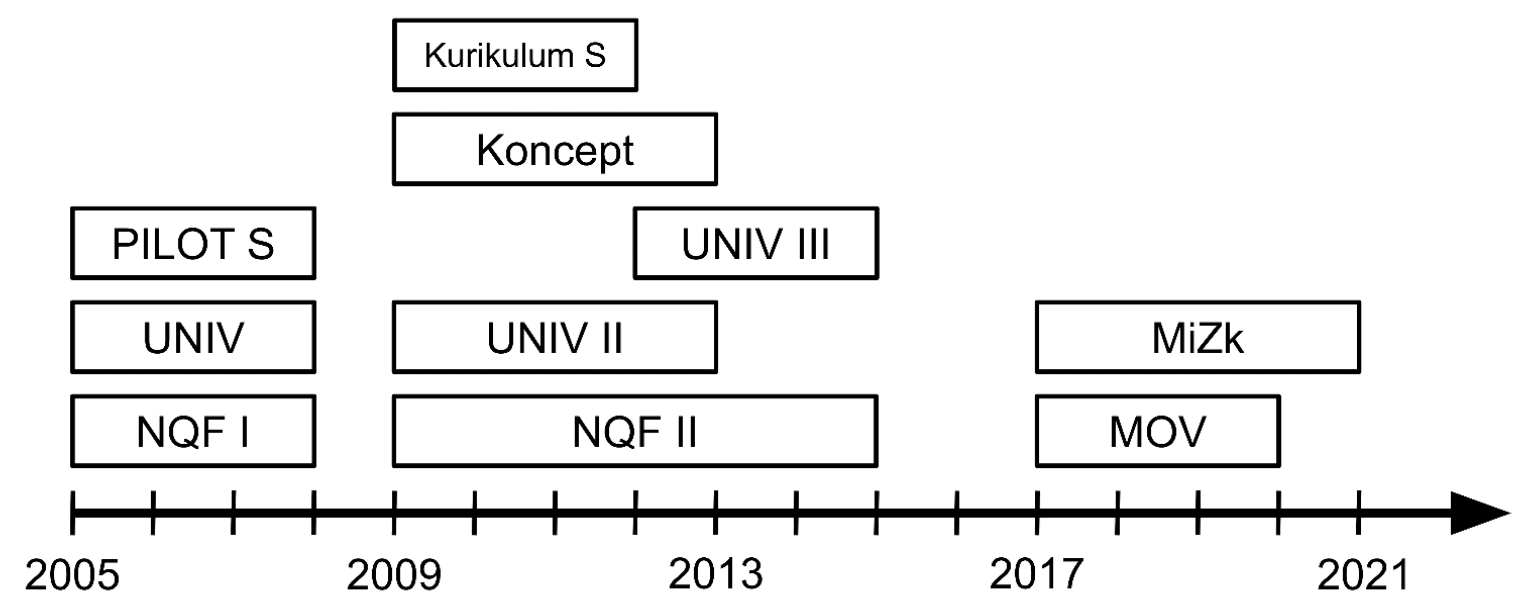

Figure 2. Timeline of selected projects

The repurposing of the NQF can be read as an attempt to expand the usability of the NQF to new contexts when progress has been stalled with regard to the original one. Building upon that, it is my contention that the particular direction of the repurposing corresponds to the prolonging of processes through which qualification standards are created or revised. From the perspective of the interviewed stakeholders in adult education (who still operate with the initial reduction of complexity), the framework becomes increasingly irrelevant. On the other hand, schools can become an offtake that better matches its speed. In terms of Rosa's (2013: 258-262) acceleration theory, the reorientation of the NQF away from the fast-paced market of non-formal adult education can be seen as an attempt to evade the influence of the economy as a dominant pacesetter. Instead, the NQF seems to seek alignment with predominantly state-run formal education institutions. The repurposing is not explicitly associated by any interviewee with the tempo the NQF has settled in, but I believe that there is an implicit understanding of how its current speed translates into usability in various contexts. 


\section{Conclusion}

The NQF and the organizations currently maintaining it find themselves in a state of frenetic standstill. The expectations of change in adult education discourse introduce a sense of urgency, pressing for faster developments. On the other hand, the field of adult education in the Czech Republic reportedly exhibits a lack of continuous development, which stakeholders could perceive as progress. While the NQF produces a steady output of new standards and examinations, prolonged processes and an accumulation of maintenance requirements indicate that it gradually takes more to produce the same. Moreover, the increasingly fast turnover of individuals only exacerbates the state since a lack of continuity impacts both the process length and the ability to maintain the original purpose. In describing the heightened activity on maintaining and gradual repurposing of the NQF, combined with the impression of a standstill as far as the original purpose is concerned, this study accounts for a paradoxical state in which the examined organizations can be simultaneously seen as inert and in flux.

This study contributes to its research field in that the outlined association with temporalization and reduction of complexity further integrates the notion of a frenetic standstill into a broader theoretical perspective. It can also facilitate tracking the frenetic standstill down in other empirical contexts. This study can be read as providing blueprints for developing a set of indicators to be used in comparative research: the rate of organizational mergers, the rate of turnover of individuals, the declarative rate of progress, the rate of organizational output, the length of internal processes, the rate with which technical and legislative measures are developed and abandoned, or the rate with which strategic documents are produced (and with which they aim to bring transformative changes). In particular, it would be interesting to compare indicators among national contexts, especially where RPL and other systems associated with flexible learning pathways exhibit varying levels of development. Such comparative research would provide valuable insights regarding factors that contribute to emergence of the frenetic standstill.

Another contribution of this study is in showing how the notion of technological change drives the discourse of lifelong learning, providing an account of the only systemic measure the Czech state (following many other states) implemented, and relating its dynamics to a gradual shift in purpose. One of the more interesting points is that the accelerating rate of change impacts the NQF itself. In this regard, it seems that at least in the observed context of state administration, social acceleration - while being largely unreflected in the discourses examined here - perpetuates itself as a relatively independent force. Focusing on social acceleration in its own right could bring valuable insights that would complement Rosa's theorization of the economy as the dominant pacesetter.

\section{Acknowledgements}

This study was funded by the Czech Science Foundation (grant number GA_19-00987S). 


\section{References}

Andersson P and Fejes A (2010) Mobility of knowledge as a recognition challenge: Experiences from Sweden. International Journal of Lifelong Education 29(2): 201-218. DOI: 10.1080/02601371003616624.

Andersson P, Fejes A and Ahn SE (2004) Recognition of prior vocational learning in Sweden. Studies in the Education of Adults 36(1): 57-71. DOI: 10.1080/02660830.2004.11661487.

Andersson P, Fejes A and Sandberg F (2013) Introducing research on recognition of prior learning. International Journal of Lifelong Education 32(4): 405-411. DOI: 10.1080/02601370.2013.778069.

Atkinson P (2017) Thinking Ethnographically. Los Angeles: SAGE.

Boeren E (2016) Lifelong Learning Participation in a Changing Policy Context: An Interdisciplinary Theory. New York: Palgrave Macmillan.

Bolton H (2020) Introduction: Why inclusivity, and why this sequence of papers? SAQA Bulletin 19(1): $1-17$.

Bolton H, Matsau L and Blom R (2020) Flexible Learning Pathways: The National Qualifications Framework Backbone. Report for the IIEP-UNESCO Research 'SDG4: Planning for flexible learning pathways in higher education'.

Buddeberg M and Hornberg S (2017) Schooling in times of acceleration. British Journal of Sociology of Education 38(1): 49-59. DOI: 10.1080/01425692.2016.1256760.

Cetrulo A and Nuvolari A (2019) Industry 4.0: Revolution or hype? Reassessing recent technological trends and their impact on labour. Journal of Industrial and Business Economics 46: 391-402. DOI: 10.1007/s40812-019-00132-y.

Commission of the European Communities (2000) A Memorandum on Lifelong Learning. Available at: https://uil.unesco.org/i/doc/lifelong-learning/policies/european-communitiesa-memorandum-on-lifelong-learning.pdf (accessed 10 September 2020).

Commission of the European Communities (1995) Teaching and Learning: Towards the Learning Society. Available at: https://op.europa.eu/en/publication-detail/-/publication/d0a8aa7a5311-4eee-904c-98fa541108d8/language-en (accessed 14 February 2021).

Cooper L, Ralphs A and Harris J (2017) Recognition of prior learning: The tensions between its inclusive intentions and constraints on its implementation. Studies in Continuing Education 39(2): 197-213. DOI: 10.1080/0158037X.2016.1273893.

Desjardins R and Ioannidou A (2020) The political economy of adult learning systems - some institutional features that promote adult learning participation. Zeitschrift für Weiterbildungsforschung 43(1): 143-168. DOI: 10.1007/s40955-020-00159-y.

Desjardins R (2020) PIAAC Thematic Review on Adult Learning. Report, OECD, FR, July.

Duvekot R, Coughlan D and Aagard K (2017) Introduction. In: Duvekot R, Coughlan D and Aagard K (eds.) The Learner at the Centre: Validation of Prior Learning Strengthens Lifelong Learning for All. Houten (NL), European Centre for Valuation Prior Learning, pp. 1-9.

Eduzměna Foundation (2019) Analýza výzev vzdělávání v České republice / Analysis of Challenges for Education in the Czech Republic. Available at: https://eduzmena.cz/wpcontent/uploads/2019/05/Eduzme\%CC\%8Cna_A4_Studie-celek_III.pdf (accessed 10 September 2020).

Frey CB and Osborne MA (2017) The future of employment: How susceptible are jobs to computerisation? Technological Forecasting \& Social Change 114(1): 254-280. DOI: 10.1016/j.techfore.2016.08.019. 
Geertz C (1973) The Interpretation of Cultures: Selected Essays. New York: Basic Books. Gleason NW (2018) Introduction. In: Gleason NW (ed.) Higher Education in the Era of the Fourth Industrial Revolution. Singapore: Palgrave Macmillan, pp. 1-12.

Hamer J (2010) Recognition of prior learning - normative assessment or co-construction of preferred identities? Australian Journal of Adult Learning 50(1): 100-115.

Harris J (1999) Ways of seeing the recognition of prior learning (RPL): What contribution can such practices make to social inclusion? Studies in the Education of Adults 31(2): 124139. DOI: 10.1080/02660830.1999.11661407.

Karttunen (2020) Organisational arrangements: Introduction. In: Duvekot R, Karttunen A, Noack $\mathrm{M}$ and Van den Brande L (eds.) Making Policy Work: Validation of Prior Learning for Education and the Labour Market. Houten (NL): European Centre for Validation Prion Learning, pp. 53-56.

Kopecký M and Šrák M (2015) Adult education and learning policy in the Czech Republic. In: Milana M and Tom N (eds) Global Perspectives on Adult Education and Learning Policy. New York: Palgrave Macmillan, pp. 29-43.

Lotz-Sisitka H, Ramsaru P and Bolton H (2017) Introduction: Researching sustainable development learning pathways towards progression in learning and work. SAQA Bulletin 17(1): $1-24$.

Luhmann N (1978) Temporalization of complexity. In: Geyer FR and van der Zouwen J (eds) Sociocybernetics. An Actor-Oriented Social Systems Approach. Leiden: Martinus Nijhoff Social Sciences Division, pp. 95-111.

Lübbe H (2009) The contraction of the present. In: Rosa H and Scheuerman WE (eds) HighSpeed Society. Social Acceleration, Power, and Modernity. University Park, PA: The Pennsylvania State University Press, pp. 159-178.

MEYS (2001) Národní program rozvoje vzdělávání v České Republice. Bílá kniha / National Program for Development of Education in the Czech Republic. A White Paper. Available at: https://www.msmt.cz/file/35405_1_1/ (accessed 10 September 2020).

MEYS (2003) Strategie rozvoje lidských zdrojů pro českou republiku / The Strategy of Human Resource Development for the Czech Republic. Available at:

http://old.nvf.cz/rozvoj_lz/dokumenty/strategie2003.pdf (accessed 10 September 2020).

MEYS (2007) Strategie celoživotního učení ČR / Strategy of Lifelong Learning in the Czech Republic. Available at:

https://www.msmt.cz/uploads/Zalezitosti_EU/strategie_2007_CZ_web_jednostrany.pdf (accessed 10 September 2020).

MEYS (2009) Analýza naplnění cílů národního programu rozvoje vzdělávání v České republice (Bílé knihy) v oblasti předškolního, základního a středního vzdělávání / Analysis of Implementation of the National Program for Development of Education in the Czech Republic (White Paper) in the Areas of Preschool, Primary and Secundary Education. Available at: http://www.msmt.cz/uploads/soubory/zakladni/AV_evaluace_BK.pdf (accessed 10 September 2020).

MEYS (2010) Průvodce dalším vzděláváním v kontextu aktivit ministerstva školství, mládeže a tělovýchovy / A Guide to Further Education and its Role in Activities of the Ministry of Education, Youth and Sports. Available at: https://www.msmt.cz/file/11567/download/ (accessed 10 September 2020).

MEYS (2015) Strategie vzdělávací politiky České republiky do roku 2020 / Strategy of Educational Policy of the Czech Republic Toward 2020. Available at: 
https://www.msmt.cz/vzdelavani/skolstvi-v-cr/strategie-vzdelavaci-politiky-2020-1 (accessed 14 February 2021).

Milana M (2017) Global Networks, Local Actions: Rethinking Adult Education Policy in the 21st Century. New York: Routledge.

Morgan J (2019) Will we work in twenty-first century capitalism? A critique of the fourth industrial revolution literature. Economy and Society 48(3): 371-398. DOI:

10.1080/03085147.2019.1620027.

National Institution of Technical and Vocational Education (2006) Národní soustava kvalifikací / National Qualifications Framework. Available at:

https://web.archive.org/web/20060621054239/http://www.nsk.nuov.cz/ (accessed 10 September 2020).

National Training Fund (2017) Dopady průmyslu 4.0 na trh práce v ČR / The Impact of Industry 4.0 on the Labor Market in the Czech Republic. Available at:

http://www.nvf.cz/cms/assets/docs/88ffb3e9f7da58fefd9741bca08796a3/794-0/dopadyprumyslu-4.0-na-trh-prace-v-cr.pdf (accessed 10 September 2020).

Office of the Government of the Czech Republic (2015) Dopady digitalizace na trh práce v ČR a $\mathrm{v}$ EU / The Impact of Digitalization on the Labor Market in the Czech Republic and the EU. Available at: https://www.vlada.cz/assets/evropske-zalezitosti/analyzy-EU/Dopadydigitalizace-na-trh-prace-CR-a-EU.pdf (accessed 10 September 2020).

Parliament of the Czech Republic (2011) Stenografický zápis 23. Schůze, 21. Září 2011 / Stenographic Record of 23th Sitting, 21 September 2011. Available at: https://www.psp.cz/eknih/2010ps/stenprot/023schuz/23-2.html (accessed 10 September 2020).

Penprase BE (2018) The fourth industrial revolution and higher education. In: Gleason NW (ed.) Higher Education in the Era of the Fourth Industrial Revolution. Singapore: Palgrave Macmillan, pp. 207-228.

Pfeiffer S (2017) The vision of "industrie 4.0" in the making - a case of future told, tamed, and traded. Nanoethics 11(1): 107-121. DOI: 10.1007/s11569-016-0280-3.

Ramsaru P (2017) Understanding learning pathways and transitioning: Perspectives from the literature. SAQA Bulletin 17(1): 73-105.

Ra S, Shrestha U, Khatiwada S, et al. (2019) The rise of technology and impact on skills.

International Journal of Training Research 17(1): 26-40. DOI:

10.1080/14480220.2019.1629727.

Rosa H (2013) Social Acceleration. A New Theory of Modernity. New York: Columbia University Press.

Sandberg F and Andersson P (2011) RPL for accreditation in higher education - as a process of mutual understanding or merely lifeworld colonisation? Assessment \& Evaluation in Higher Education 36(7): 767-780. DOI: 10.1080/02602938.2010.488793.

Sandberg F and Kubiak C (2013) Recognition of prior learning, self-realisation and identity within Axel Honneth's theory of recognition. Studies in Continuing Education 35(3): 351365. DOI: 10.1080/0158037X.2013.768230.

Smith L and Clayton B (2009) Recognising Non-Formal and Informal Learning: Participant Insights and Perspectives. Report, NCVER, AU.

Sutherland T (2014) Getting nowhere fast: A teleological conception of socio-technical acceleration. Time \& Society 23(1): 49-68. DOI: 10.1177/0961463X13500793.

Trowler P (1996) Angels in marble? Accrediting prior experiential learning in higher education. Studies in Higher Education 21(1): 17-30. DOI: 10.1080/03075079612331381427. 
Villalba E (2020) Validation in Europe. State of play. In: Duvekot R, Karttunen A, Noack M and Van den Brande L (eds.) Making Policy Work: Validation of Prior Learning for Education and the Labour Market. Houten (NL): European Centre for Validation Prion Learning, pp. $25-40$.

Wall S (2015) Focused ethnography: A methodological adaption for social research in emerging contexts. Forum Qualitative Sozialforschung / Forum: Qualitative Social Research 16(1). 